\title{
Models of Energy Use: Putty-Putty Versus Putty-Clay
}

\author{
By Andrew AtKeson and Patrick J. KehoE*
}

Energy economists have identified two salient features of data on energy use and energy prices: In time-series data, energy use does not change much with energy price changes. (See Ernst R. Berndt and David O. Wood, 1975.) In cross-section data across countries, energy use is responsive to international differences in energy prices. (See James M. Griffin and Paul R. Gregory, 1976; Robert S. Pindyck, 1979.) In this article, we consider two models of energy use designed to reproduce the low short-run and high long-run elasticities of energy use seen in the data. We contrast the models' implications for capital and output as well as energy use in the time series and in the cross section.

One model we consider is a putty-putty model developed by Pindyck and Julio J. Rotemberg (1983). The key features of this model are that capital and energy are highly complementary and that capital is subject to adjustment costs. Because of the adjustment costs, the capital stock moves slowly over time in response to changes in energy prices. Since energy and capital are highly complementary in production, energy moves slowly as well. In the long run, the capital stock adjusts to permanent differences in energy prices and so does energy use.

The other model is a putty-clay model in which a large variety of types of capital goods are combined with energy in different fixed proportions. The putty-clay model delivers a low elasticity of energy use in the short run, because existing capital uses energy in fixed proportions. In the long run, in response to permanent differences in energy prices, agents invest in different capital goods

\footnotetext{
* Atkeson: Research Department, Federal Reserve Bank of Minneapolis, Minneapolis, MN 55480, and National Bureau of Economic Research; Kehoe: Department of Economics, University of Pennsylvania, Philadelphia, PA 19104, Federal Reserve Bank of Minneapolis, and National Bureau of Economic Research. Atkeson thanks the National Science Foundation (NSF) and the Alfred P. Sloan Foundation for support; Kehoe thanks the NSF and the Ronald Lauder Foundation for support. The views expressed herein are those of the authors and not necessarily those of the Federal Reserve Bank of Minneapolis or the Federal Reserve System.
}

with different fixed energy intensities. As a result, in the long run, energy use is responsive to differences in energy prices.

When we compare the Pindyck-Rotemberg putty-putty model with the putty-clay model, we find that the models have similar implications for how energy use responds to energy prices in the time series and in the cross section. When simulated, both models deliver similar predictions for the evolution of energy use and energy expenditure relative to gross domestic product (GDP). The models show some minor differences in their time-series implications for the capital-to-energy ratio. In the putty-clay model, the capital-to-energy ratio lags the corresponding ratio in the data, while in the Pindyck-Rotemberg model, it does not.

The major difference between the models is in their cross-section implications for how capital and output respond to permanent differences in energy prices. In the Pindyck-Rotemberg model, countries with permanently higher energy prices have dramatically lower capital stocks and output, while in the putty-clay model, they do not. The response of capital in the Pindyck-Rotemberg model is much larger than that estimated by Griffin and Gregory (1976) and Pindyck (1979) in the cross section. In contrast, the response of capital in the putty-clay model is similar to estimates in those studies.

One of the economic implications of this difference is that the models give drastically different predictions about the effect of an energy tax on output. In a simplified version of the PindyckRotemberg model, we find that an energy tax that doubles the price of energy leads to a fall in output in the long run of 33 percent. In contrast, the same tax in the putty-clay model leads to a fall in output of only 5.3 percent. This drop in output in the Pindyck-Rotemberg model is an order of magnitude larger than typical measures of the effects of energy taxes, such as those of Lawrence $\mathrm{H}$. Goulder $(1992,1993,1995)$ and Dale W. Jorgenson and Peter J. Wilcoxen (1993). The drop in output in the putty-clay model is comparable to the drop shown in these studies. 
This difference in the cross-section implications of the two models stems from the different ways the models deliver the low short-run and high long-run elasticities of energy use. In the Pindyck-Rotemberg model, capital and energy are highly complementary in both the short run and the long run. Since capital and energy are so complementary, energy use responds a lot in the long run only if the capital stock does as well. In contrast, in the putty-clay model, capital and energy are highly complementary in the short run, but are substitutable in the long run. Thus, in the short run, energy use does not adjust to energy price changes. In the long run, however, the capital-to-energy ratio changes as agents invest in new types of capital with different energy intensities. Thus, in the long run, energy use changes with energy prices even if the capital stock does not.

In most quantitative work to date, economists have used the now standard putty-putty model of production with smooth substitution between capital and other factors. In that model, the capital stock of the economy can be aggregated into a single state variable. In contrast, in the putty-clay model, capital goods come in a wide variety of types indexed by the proportions in which they can be combined with other factors, and in general, no single capital aggregate can be formed. The concern that this feature of the putty-clay model might give rise to an intractable curse of dimensionality may have hindered its application.

In applying this putty-clay model to data on energy use, we find that despite the large number of capital goods, the model does not suffer from the curse of dimensionality. In particular, we show that as long as all types of existing capital are fully utilized in equilibrium, the solution to the putty-clay model with many capital goods is equivalent to the solution to a model with only two state variables: aggregate capital services and aggregate energy use. Moreover, when this condition that all existing types of capital are fully utilized in equilibrium is satisfied, then in each period, all investment is concentrated in one type of capital with one energy intensity. Thus, the condition that all existing types of capital be fully utilized in equilibrium simplifies the solution to the model considerably. This solution applies to the putty-clay model of energy because energy costs are a small fraction of the total cost of capital and energy, and the energy price does not vary so much that it ever becomes optimal to leave energy-intensive units of capital unutilized.

In the putty-clay model, capital is putty-clay in terms of its energy intensity. Our theoretical model builds on insights from an earlier literature in which capital is putty-clay in terms of its labor intensity. This literature begins with the work of Leif Johansen (1959), who developed the basic putty-clay setup in a deterministic growth model. Subsequently, Robert M. Solow (1962), Guillermo A. Calvo (1967, 1976), E. Sheshinski (1967), David Cass and Joseph E. Stiglitz (1969), and many others investigate the properties of this model.

For some recent work on a vintage approach to modeling energy use, see Charles S. Struckmeyer (1987). Plutarchos Sakellaris (1997) uses a vintage model of capital accumulation to address the link between shocks to factor prices and firm profitability. In solving the model, Sakellaris uses a full utilization condition which is similar to ours. For some work incorporating imperfect competition into a model of energy use, see Rotemberg and Michael Woodford (1996).

\section{The Data}

In this section, we discuss the time-series and cross-section data on energy prices, energy use, and energy expenditure. We argue that in the time series, energy use is fairly inelastic, while in the cross section, it is fairly elastic.

For the time series, we use current annual data on energy prices, energy use, and energy expenditure for the U.S. economy for the period 1960-1994. We interpret our putty-putty and putty-clay models as covering all sectors of the economy except the energy-producing sector. As a result, in our measures of output and energy use, we exclude the output and energy use of the energy sector of the U.S. economy. To obtain an aggregate series on energy use for the U.S. economy, we construct a constant-price measure of the use of electricity, petroleum, coal, and natural gas. Correspondingly, our aggregate energy price is the ratio of energy use measured in current prices to energy use measured in constant prices. A full explanation of the sources and methods used in our data construction is given in the Appendix. 


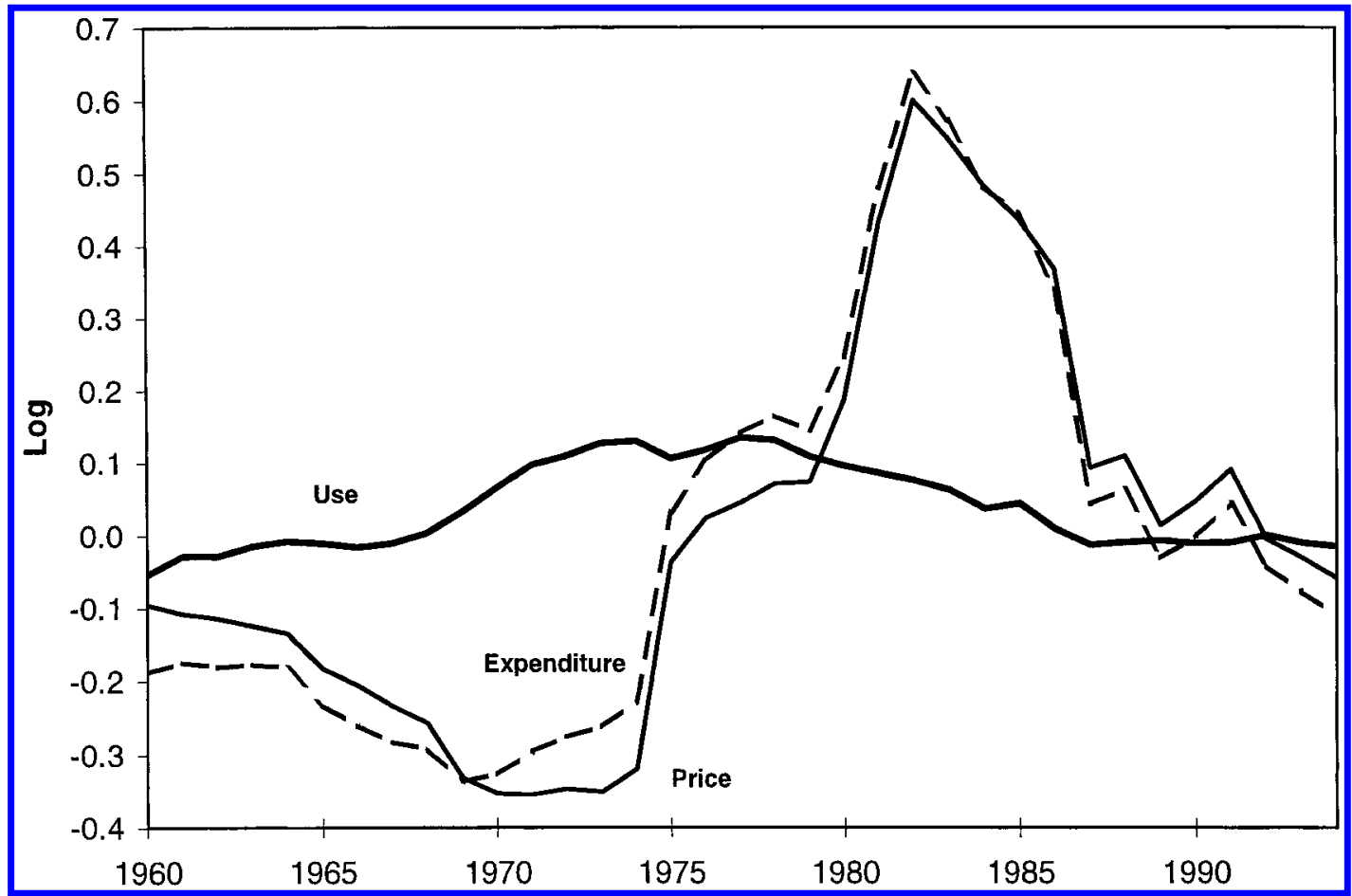

Figure 1. Energy Price, Use, and Expenditure U.S. DATA $1960-1994$

Notes: Energy price is the ratio of the implicit deflator for energy to the GDP deflator; energy use is the ratio of real energy expenditure to real GDP; energy expenditure is the ratio of nominal energy expenditure to nominal GDP. All series are measured in logarithms and demeaned. See the Appendix for details.

In Figure 1, we plot the logarithms of our data on the energy price relative to the GDP deflator, energy use relative to real GDP, and nominal energy expenditure relative to nominal GDP for the period 1960-1994. These series have all been normalized to have mean zero. As is evident in this figure, energy use fluctuates a lot less than the energy price or energy expenditure, while the fluctuations in energy expenditure are very similar to those in the energy price. These data suggest that in the time series, energy use responds rather inelastically to changes in energy prices. This figure corroborates the finding by Berndt and Wood (1975) that energy use moves less than energy prices in the time series.

The relationships among energy prices, use, and expenditure apparent in Figure 1 contrast sharply with what is found when energy prices, use, and expenditure are compared across coun- tries. Griffin and Gregory (1976) and Pindyck (1979) report that there is a wide disparity in energy prices across countries in their data, due primarily to differences in energy taxes, tariffs, and import controls, but these international variations in energy prices do not closely track the observed international variations in energy expenditure shares. In particular, both of these studies estimate an own-price elasticity of energy use of 0.8. Moreover, Griffin and Gregory (1976) do not reject the hypothesis that energy enters production in a Cobb-Douglas relationship with other factors. Thus, in the cross section, energy use is fairly elastic.

\section{The Pindyck-Rotemberg Model}

Pindyck and Rotemberg (1983) develop and estimate a putty-putty model of production that includes capital, energy, labor, and materials. 
Their model has adjustment costs on capital and labor and a translog cost function describing variable costs due to materials and energy. They estimate this model using a data set that covers the manufacturing sector in the United States during the years 1948-1971. Pindyck and Rotemberg (1983) find that their estimated model produces both low elasticities of energy use in the time series and high elasticities of energy use in the cross section.

The basic mechanism of their model is as follows. Capital and energy are highly complementary in both the short run and the long run, so capital-to-energy ratios never move much. In the short run, adjustment costs keep capital from changing in response to energy prices, so energy use does not change much either. In the long run, capital does respond, but since capital and energy are so complementary, energy use responds a lot in the long run only if the capital stock does as well. This basic mechanism implies that in a cross section, the capital stock falls substantially when the energy price rises. More precisely, Pindyck and Rotemberg (1983 Table 2 p. 1074) estimate the cross-section Allen elasticity of the capital stock with respect to the energy price to be -0.9 , so a 1 -percent increase in energy prices drives down energy by 1 percent, drives down capital by 0.9 percent, and raises the capital-to-energy ratio by only 0.1 percent.

This implication is not consistent with the cross-section studies of Griffin and Gregory (1976) and Pindyck (1979). These studies find that when output is held fixed, capital stays the same or even rises when energy prices are higher. Griffin and Gregory's point estimates of the cross-section Allen elasticity of the capital stock with respect to the energy price range from 0.08 to 0.17 , while Pindyck's estimates range from 0.03 to 0.12 .

To illustrate the basic idea behind the Pindyck-Rotemberg model, we present a simplified version in which we abstract from materials and use constant-elasticity-of-substitution (CES) production functions instead of a trans$\log$ cost function. We show that this model reproduces the time-series and cross-section patterns of energy use in the data. Throughout, we interpret the cross-section elasticities in the data as corresponding to cross-steady-state elasticities in our theoretical models. We show that the model has problems, however, in reproducing the patterns of the capital stock and output in the cross section.

In our simplified version of the PindyckRotemberg model, we index time by $t=0,1$, $2, \ldots$. Output is produced with inputs of capital, energy, and labor. There are adjustment costs for investment in new capital. Energy is imported from abroad at an exogenous world price $p_{t}$, which is random, and energy imports are paid for with exports of output, with trade balanced in every period. The preferences of the representative agent are given by

$$
E_{0} \sum_{t=0}^{\infty} \beta^{t} u\left(c_{t}\right)
$$

where $c_{t}$ is consumption and $0<\beta<1$ is the discount factor. Labor $l_{t}$ is supplied inelastically and is set equal to the consumer's time endowment, which equals one.

The equilibrium allocation for this economy is a set of sequences for capital, investment, energy use, and consumption $\left\{k_{t+1}, x_{t}, e_{t}, c_{t}\right\}$ that maximizes (1) subject to

$$
\begin{gathered}
c_{t}+x_{t}=G\left(F\left(k_{t}, e_{t}\right), l_{t}\right)-p_{t} e_{t} \\
k_{t+1}=(1-\delta) k_{t}+x_{t}-\phi\left(x_{t} / k_{t}\right) k_{t}
\end{gathered}
$$

with $k_{0}, l_{t}=1$, and the stochastic process for energy prices taken as given. Here $\phi$ captures the adjustment costs on investment, $\delta$ is the depreciation rate, $F$ is a constant-returns-toscale function aggregating capital and energy into capital services, and $G$ is a constantreturns-to-scale production function aggregating capital services and labor into output. We assume that $F$ and $G$ are CES production functions with

$$
\begin{aligned}
& F(k, e)=\left(\omega_{F} k^{1-a}+\left(1-\omega_{F}\right) e^{1-a}\right)^{1 / 1-a} \\
& G(F, l)=\left(\omega_{G} F^{1-b}+\left(1-\omega_{G}\right) l^{1-b}\right)^{1 / 1-b}
\end{aligned}
$$

where $a, b, \omega_{F}$, and $\omega_{G}$ are parameters. Adjustment costs are given by $\phi(x / k)=(D / 2)(x /$ $k-\delta)^{2}$, where $D$ is the adjustment cost parameter. 
We choose the parameters of the production functions $F$ and $G$ and the steady-state energy price $\bar{p}$ to reproduce the elasticity estimates in Pindyck and Rotemberg (1983) and the factor shares in our data. The short-run Allen elasticity of energy use with respect to the energy price is found by differentiating the first-order conditions of the cost-minimization problem with output, the wage rate, and the capital stock held fixed. Doing so yields the formula

$$
\begin{aligned}
\varepsilon_{s r} & =\left.\frac{d \log e}{d \log p}\right|_{\begin{array}{c}
d G=0 \\
d w=0 \\
d k=0
\end{array}} \\
& =-\frac{1}{\left(1-s_{e}\right) a+s_{e} b / s_{l}}
\end{aligned}
$$

where $s_{l}$ is the share of output paid to labor, $\left(1-s_{l}\right) s_{e}$ is the share of output paid to energy, and $\left(1-s_{l}\right)\left(1-s_{e}\right)$ is the share of output paid to capital. The cross-steady-state Allen elasticity of energy use with respect to the energy price is found by differentiating the first-order conditions of the cost-minimization problem with output, the wage rate, and the rental rate on capital held fixed. This differentiation yields the formula

$$
\begin{aligned}
\varepsilon_{l r} & =\left.\frac{d \log e}{d \log p}\right|_{\begin{array}{c}
d G=0 \\
d w=0 \\
d r=0
\end{array}} \\
& =-\frac{\left(1-s_{e}\right)}{a}-\frac{s_{l} s_{e}}{b} .
\end{aligned}
$$

With data on factor shares given, these elasticities are simple formulas of the two curvature parameters $a$ and $b$.

In our data, mean factor shares are $s_{l}=0.57$ for labor and $\left(1-s_{l}\right) s_{e}=0.043$ for energy. We choose the curvature parameters $a$ and $b$ so that our model reproduces a short-run elasticity of energy use of $-1 / 3$ and a cross-steady-state Allen elasticity of energy use with respect to the energy price of -1 . These elasticities match those reported in Pindyck and Rotemberg (1983 Table $2)$. The corresponding curvature parameters are $a=3.33$ and $b=0.079$. Recall that Pindyck and Rotemberg (1983) estimate the cross-steady-state
Allen elasticity of the capital stock with respect to the energy price to be -0.9 . In our version of their model, this elasticity is -0.7 , so our model leads to similar implications.

To evaluate the ability of this PindyckRotemberg model to reproduce time-series data on the energy price and energy use, we parameterize the rest of the model and simulate it, feeding in the data on the energy price to obtain predictions for the time paths of energy use, capital, and output. For the energy price process, we follow In Moo Kim and Prakash Loungani (1992) and Mary G. Finn (1995) and estimate an ARMA $(1,1)$ process parameterized by

$$
\begin{aligned}
\log p_{t+1}= & \left(1-\rho_{p}\right) \log \bar{p}+\rho_{p} \log p_{t} \\
& +\eta \varepsilon_{p t-1}+\varepsilon_{p t}
\end{aligned}
$$

where $\varepsilon_{p t} \sim N\left(0, \sigma_{p}^{2}\right)$ and $\bar{p}$ is the average energy price in our data. Using our annual energy price data from the 1960-1994 period, we estimate that $\rho_{p}=0.90, \bar{p}=0.92, \eta=0.35$, and $\sigma_{p}=0.108$. For the consumer's preferences, we choose $u(c)=\log (c)$ and set $\beta=$ 0.96 . We set the depreciation rate $\delta=0.1$ and the adjustment cost parameter $D=1$.

In Figure 2, we compare the time series for the logarithm of the ratio of energy expenditure to nominal GDP and the ratio of energy use to real GDP for the model and the data for the period 1960-1994. Considering that we use Pindyck and Rotemberg's (1983) estimates of the elasticity of energy use obtained from data that does not include the energy price shocks of the 1970's and 1980's, the model appears to reproduce the time-series behavior of energy use pretty well. In the figure, energy use as given in the model appears to be more responsive to the energy price than in the data. The fit between the model and these data improves if the production parameters are set to give a smaller short-run elasticity of energy use.

In Figure 3, we compare the time series for the logarithm of the capital-to-energy ratio for the model and the data for the period 19601994. In the model, the capital-to-energy ratio is more responsive to changes in the energy price than in the data. Again, the fit improves if the production parameters are set to give a smaller short-run elasticity of energy use. 


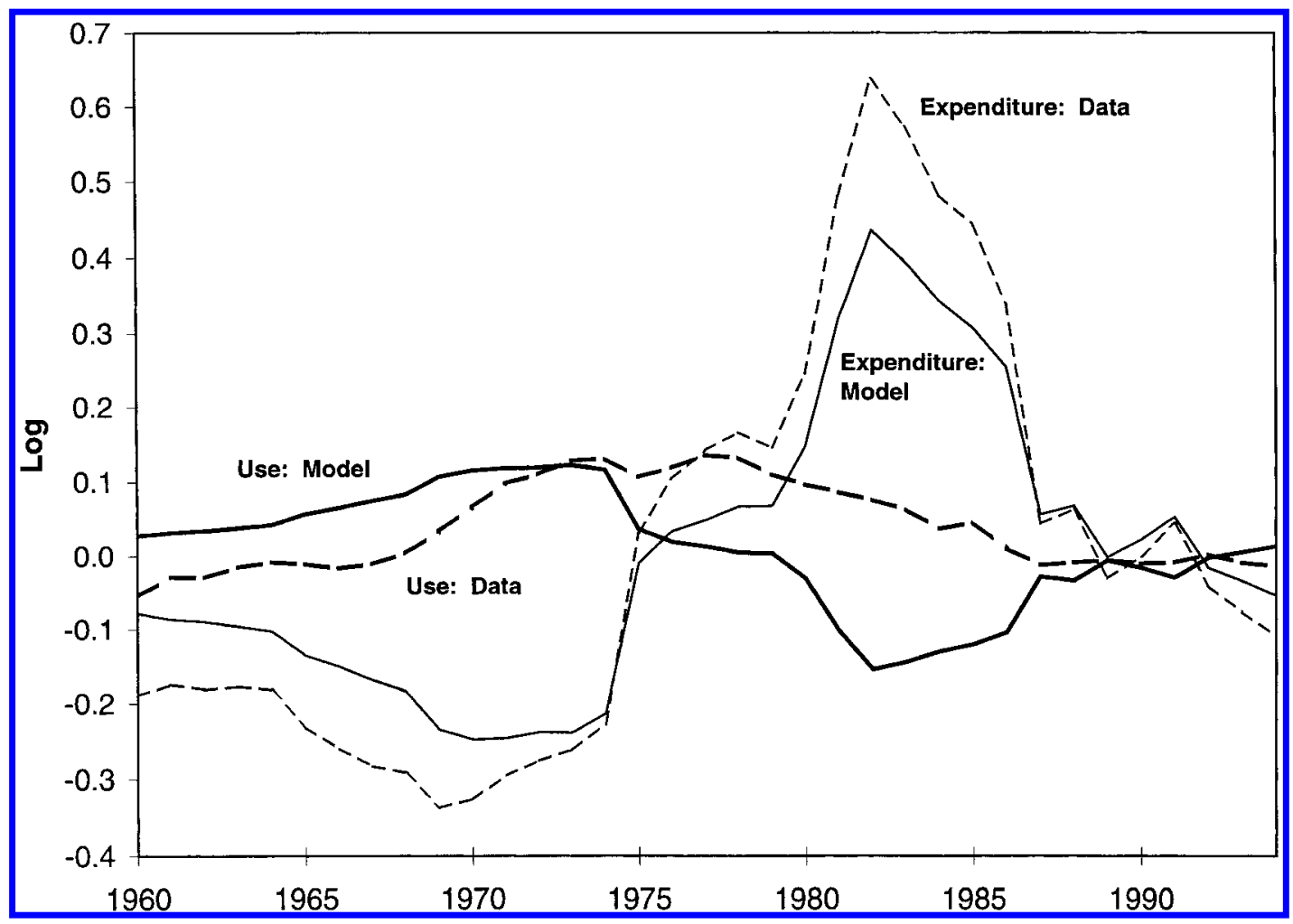

Figure 2. ENERgy ExPENDITURE AND USE

Pindyck-Rotemberg Model versus U.S. Data 1960-1994

Notes: Energy expenditure is the ratio of nominal energy expenditure to nominal GDP; energy use is the ratio of real energy expenditure to real GDP. All series are measured in logarithms and demeaned. See the Appendix for details.

To highlight the difference between the Pindyck-Rotemberg model and the putty-clay model, we compute the drop in output that would occur across steady states if energy prices were to double as the result of an energy tax. We assume that the revenue collected is spent on public goods that affect neither steadystate real returns nor the steady-state marginal product of capital. In our simplified version of the Pindyck-Rotemberg model, a doubling of the energy price leads to a 33-percent drop in output and a 78-percent drop in the capital stock.

Goulder (1992, 1993, 1995) and Jorgenson and Wilcoxen (1993) examine the impact of increased carbon taxes on output. The numbers in these studies are not directly comparable to the ones calculated here, because they consider a carbon tax that does not cover all forms of energy, thus allowing some substitution to untaxed forms of energy. Nevertheless, we find their numbers instructive. Goulder and Jorgenson and Wilcoxen find that the loss in GDP is of the same order of magnitude as the revenue raised from the taxes. In our version of the Pindyck-Rotemberg model, the revenue raised from an energy tax that doubles the energy price is 1.3 percent of long-run GDP. Clearly, then, the impact of energy taxes on long-run output in this model is many times larger than the revenue raised by such taxes.

\section{A Putty-Clay Model}

In this section, we present an alternative model that matches the observation that energy use is inelastic in the time series and elastic in the cross section. In this alternative model, 


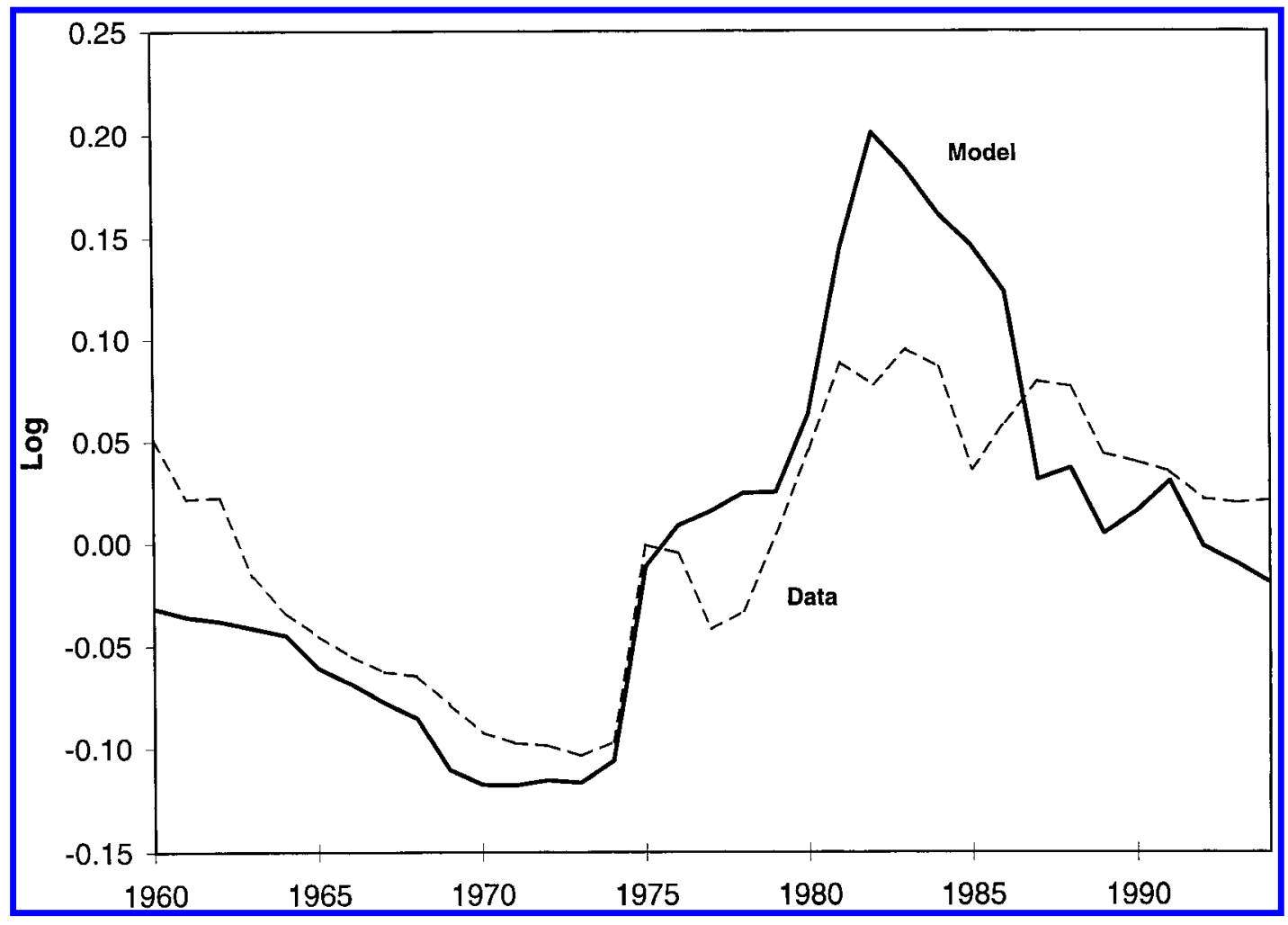

Figure 3. Capital-Energy Ratio

Pindyck-Rotemberg Model versus U.S. DATA 1960-1994

Notes: Capital-energy ratio is the ratio of the capital stock measured using the perpetual inventory method in real energy expenditure. See the Appendix for details.

capital is putty-clay in terms of its energy intensity. There is a continuum of capital goods that is combined with energy in different fixed proportions. The basic idea behind the model is as follows. Since capital goods are designed with a fixed energy intensity when constructed, existing capital requires energy in fixed proportions to provide capital services. Therefore, in the short run, energy use is inelastic, because there is no way to substitute existing capital and energy. Over time, new capital goods embodying a new energy intensity can be installed so that, in the long run, energy use is elastic with respect to the energy price. In what follows, we present the model, develop a method for solving the model, and present our results.

As before, output is produced with inputs of capital, energy, and labor. Again, energy is imported from abroad at an exogenous world price $p_{t}$, which is random, and energy imports are paid for with exports of output, with trade balanced in every period. Now, however, a variety of differentiated capital goods exists with types indexed by $v \in V$. A unit of capital of type $v$ provides capital services in production only in combination with $1 / v$ units of energy. If $k$ units of capital of type $v$ are combined with $e$ units of energy, where $e>k / v$, then the energy in excess of $k / v$ is wasted. If $e<k / v$, then the capital in excess of $e v$ is left idle. Use of $k$ units of capital of type $v$, together with $e$ units of energy, yields

$$
(\min (k / v, e)) f(v)
$$

units of capital services, where $f(v), f^{\prime}(v) \geq 0$, and $f^{\prime \prime}(v)<0$.

Heuristically, the relationship between this 
production function and more typical puttyputty production functions can be understood as follows. Consider a constant-returns-to-scale function describing capital services $F(k, e)$, where $k$ is the capital stock and $e$ is energy use. Production of capital services may be written as $e f(v)$, where $v=k / e$ and $f(v)=F(v, 1)$. Thus, capital services can be expressed as a function of the energy intensity of the capital stock $v$ and energy use $e$. To obtain the puttyclay model, suppose that $v$, the energy intensity of the existing capital stock, is fixed as an attribute of the existing capital, and let the output of capital services be the same function of energy use and capital as given above. Since at most $k / v$ units of energy $e$ can be used productively with $k$ units of capital of type $v$, equation (7) follows.

The stock of capital in this economy at time $t$ is represented as a function $k_{t}: V \rightarrow[0, \infty)$, where $k_{t}(v)$ is the stock of capital of type $v$. The allocation of total energy use $m_{t}$ is represented as a function $e_{t}: V \rightarrow[0, \infty)$, with $e_{t}(v)$ representing the quantity of energy used in production in combination with capital of type $v$. Thus, inputs of capital of different types $k_{t}$ and energy $m_{t}$ allocated according to $e_{t}$ yield aggregate capital services $z_{t}$ with

$$
z_{t}=\int_{v}\left(\min \left(k_{t}(v) / v, e_{t}(v)\right)\right) f(v) d v
$$

Output is produced by combining capital services $z_{t}$ and labor $l_{t}$ in a constant-returns-toscale production function $G\left(z_{t}, l_{t}\right)$. Value added in this economy is given by

$$
y_{t}=G\left(z_{t}, l_{t}\right)-p_{t} m_{t}
$$

where $m_{t}=\int_{v} e_{t}(v) d v$ is aggregate energy use.

We assume that all types of capital depreciate at the same rate $\delta$ and that investment in each type of capital $x_{t}(v)$ must be nonnegative, so

$$
x_{t}(v)=k_{t+1}(v)-(1-\delta) k_{t}(v) \geq 0
$$

for all $v \in V$. Aggregate consumption is denoted $c_{t}$, and the aggregate resource constraint is given by

$$
c_{t}+\int_{v} x_{t}(v) d v=y_{t} .
$$

The preferences of the representative agent are given by (1) and labor $l_{t}$ is supplied inelastically.

The equilibrium allocation for this economy can be found as the solution to the planning problem of choosing sequences of functions $\left\{k_{t+1}, x_{t}, e_{t}, z_{t}, m_{t}, y_{t}, c_{t}\right\}$ to maximize equation (1) subject to constraints (9), (10), (11),

$$
\begin{gathered}
z_{t}=\int_{v} e_{t}(v) f(v) d v \\
m_{t}=\int_{v} e_{t}(v) d v \\
0 \leq e_{t}(v) \leq k_{t}(v) / v
\end{gathered}
$$

for all $v \in V$, with the function $k_{0}$ taken as given. The use of constraints (12) and (14) in place of equation (8) is justified by the observation that it is never optimal to use more energy than can be productively employed with the current capital stock.

As stated here, this planning problem has endogenous state variables $k_{t}(v)$ of dimension equal to the number of elements in $V$. To allow smooth substitution between energy and other inputs in the long run, the number of elements in $V$ must be large or even infinite. Thus, the curse of dimensionality prevents a direct attack on this problem. In what follows, we show that if all existing capital goods are always fully utilized in equilibrium, then the state variables function $k$ can be reduced to two aggregate state variables, regardless of the number of elements in $V$.

We begin by analyzing the decision to utilize existing capital goods. Observe that this decision is static. Clearly, given a realization of $p_{t}$ and a capital stock function $k_{t}(v)$, the choice of energy use function $e_{t}(v)$ at $t$ maximizes (9) subject to constraints (12), (13), and (14). Analysis of this problem yields the following.

PROPOSITION 1 (A Cutoff Rule): Given $a$ capital stock function $k_{t}$ and energy price $p_{t}$, there is a cutoff type of capital $v_{t}^{*}$ such that 
capital of types $v>v_{t}^{*}$ is fully utilized at $t$ and capital of types $v<v_{t}^{*}$ is not utilized at all. This cutoff type of capital $v_{t}^{*}$ is increasing in $p_{t}$.

PROOF:

Consider the Lagrangian

$$
\begin{aligned}
& \max G\left(\int_{v} e(v) f(v) d v, 1\right)-p \int_{v} e(v) d v \\
& +\int_{v} \mu(v)(k(v)-e(v) v) d v \\
& +\int_{v} \xi(v) e(v) d v .
\end{aligned}
$$

Observe that for any type of capital $v$ such that $k(v)>0, \xi(v)=0$ if $\mu(v)>0$, and $\mu(v)=0$ if $\xi(v)>0$. The first-order conditions for this problem include $G_{z}(z, 1) f(v)-p=\mu(v) v-$ $\xi(v)$, where $z$ is given as in (12) and $G_{z}$ is the partial derivative of $G$ with respect to its first argument. From this first-order condition and the condition that all of the Lagrange multipliers are nonnegative, we get the result that $\mu(v) v=$ $\max \left[G_{z}(z, 1) f(v)-p, 0\right]$ for any type of capital $v$ for which $k(v)>0$. Thus, existing capital of type $v$ is fully utilized if $G_{z}(z$, 1) $f(v)-p>0$ and not utilized at all if $G_{z}(z$, 1) $f(v)-p<0$. Since $f(v)$ is strictly increasing in $v$, the result that capital usage is determined by a cutoff rule is established. The cutoff type $v^{*}$ solves the equation

$$
G_{z}(z, 1) f\left(v^{*}\right)-p=0
$$

and is increasing in $p$.

We now turn to the main result we use for solving this putty-clay model. We present a restricted programming problem with two state variables $(z$ and $m$ ), which we refer to as $a g$ gregate capital services and aggregate energy use. We then show that if the solution to this second problem satisfies the cutoff rule for capital utilization as summarized in Proposition 1, then we can use it to construct the solution to the original planning problem and thus to construct the equilibrium of this model economy.
[It is worth noting for later use that since in this model $\int k_{t+1}(v) d v=(1-\delta) \int k_{t}(v) d v+$ $\int x_{t}(v) d v$, the aggregate capital stock is still measured in the standard way by using the perpetual inventory method.]

Consider the restricted planning problem of choosing sequences of functions $\left\{x_{t}, z_{t+1}\right.$, $\left.m_{t+1}, y_{t}, c_{t}\right\}$ to maximize (1) subject to constraints (9), (11),

$$
\begin{aligned}
& z_{t+1} \leq(1-\delta) z_{t}+\int_{v} x_{t}(v) \frac{f(v)}{v} d v \\
& m_{t+1} \geq(1-\delta) m_{t}+\int_{v} x_{t}(v) \frac{1}{v} d v
\end{aligned}
$$

with $x_{t}(v) \geq 0$ for all $v \in V$, with the function $k_{0}$ and scalars $z_{0}=\int_{v} k_{0}(v)(f(v) / v) d v$ and $m_{0}=\int_{v}\left(k_{0}(v) / v\right) d v$ given.

We use the solution to this restricted planning problem to construct a candidate solution to our original planning problem as follows. Let $\left\{x_{t}\right.$, $\left.z_{t+1}, m_{t+1}, y_{t}, c_{t}\right\}$ be the solution to the restricted planning problem, with $z_{0}$ and $m_{0}$ defined as above. Construct sequences $\left\{k_{t+1}, e_{t}\right\}$ using $x_{t}$ and (10), and set $e_{t}(v)=k_{t}(v) / v$ for all $v$. The resulting collection of sequences constructed in this way $\left\{k_{t+1}, x_{t}, e_{t}, z_{t}, m_{t}, y_{t}, c_{t}\right\}$ satisfies the constraints of the original planning problem. We now show that if the constructed allocation also satisfies the cutoff rule in Proposition 1 under which all existing capital is in fact fully utilized, then it solves our original planning problem.

PROPOSITION 2 (An Equivalent Problem): Given the function $k_{0}, z_{0}$, and $m_{0}$, let $\left\{x_{t}, z_{t+1}\right.$, $\left.m_{t+1}, y_{t}, c_{t}\right\}$ be the solution to the restricted planning problem. Let $\left\{k_{t+1}, x_{t}, e_{t}, z_{t}, m_{t}, y_{t}, c_{t}\right\}$ be the candidate solution to the original planning problem derived as above. Let $\hat{V}_{t}$ be the set of capital types $v$ such that $k_{t}(v)>0$. If $v>v_{t}^{*}$ for all $v \in$ $\hat{V}_{t}$, with $v_{t}^{*}$ defined as in Proposition 1, then our candidate solution solves the original planning problem and is an equilibrium of the model.

\section{PROOF:}

Under the assumption that all types of capital are fully utilized, the constraints of our original 
and restricted planning problems are identical. Clearly, the objectives in these two problems are identical as well. Thus, our candidate solution solves the original problem.

We now show that in the solution to our restricted planning problem, in each period, there is positive investment in at most one type of capital.

PROPOSITION 3 (One Type of Investment): Given the function $k_{0}, z_{0}$, and $m_{0}$, let $\left\{x_{t}, z_{t+1}\right.$, $\left.m_{t+1}, y_{t}, c_{t}\right\}$ be the solution to the restricted planning problem. Then $x_{t}(v)>0$ for at most one type of capital $v$.

\section{PROOF:}

Let $\lambda_{t}^{c}, \lambda_{t}^{z}, \lambda_{t}^{m}$, and $\lambda_{t}^{x}(v)$ be the Lagrange multipliers on constraints (11), (16), (17), and the constraint $x_{t}(v) \geq 0$, respectively. Taking the first-order condition with respect to $x_{t}(v)$, we get

$$
\lambda_{t}^{x}(v)=\lambda_{t}^{c}-\lambda_{t}^{z} f(v) / v+\lambda_{t}^{m} / v .
$$

Investment $x_{t}(v)>0$ only if $\lambda_{t}^{x}(v)=0$. Furthermore, this multiplier is nonnegative, so zero is its minimum value. Thus, to prove the proposition, we show that $\lambda_{t}^{x}(v)$ has a unique minimum. Equivalently, we show that the term $h(v)=\lambda_{t}^{z} f(v) / v-$ $\lambda_{t}^{m} / v$ has a unique maximum. The multipliers $\lambda_{t}^{z}$ and $\lambda_{t}^{m}$ are positive. The maximum of $h(v)$ is attained at a point $\bar{v}$ that solves

$$
h^{\prime}(\bar{v})=\lambda_{t}^{z} \frac{\left(f^{\prime}(\bar{v}) \bar{v}-f(\bar{v})\right)}{\bar{v}^{2}}+\lambda_{t}^{m} \frac{1}{\bar{v}^{2}}=0 .
$$

Notice that for all $v, h^{\prime}(v)$ and

$$
h^{\prime}(v) v^{2}=\lambda_{t}^{z}\left(f^{\prime}(v) v-f(v)\right)+\lambda_{t}^{m}
$$

have the same sign. The derivative of $h^{\prime}(v) v^{2}$ is $\lambda_{t}^{z} f^{\prime \prime}(v)$, which is negative, since $\lambda_{t}^{z}$ is positive and $f(v)$ is strictly concave, and hence $h^{\prime}(v) v^{2}$ is strictly decreasing. Thus, since $h^{\prime}(v)$ and $h^{\prime}(v) v^{2}$ have the same signs, for $v<\bar{v}$, $h^{\prime}(v)>0$, while for $v>\bar{v}, h^{\prime}(v)<0$. This implies that $h(v)$ has a unique maximum and $\lambda_{t}^{x}(v)$ has a unique minimum and proves that there is at most one $v$ for which $x_{t}(v)=0$.

It is worth noting that one can construct an example in which more than one type of capital receives positive investment if some types of capital are left idle in some states of nature.

To examine the implications of this putty-clay model for time-series and cross-section data, we parameterize the model as follows. We let the production functions $F$ and $G$ be Cobb-Douglas. In this case, the only parameters for the production functions that need to be set are the factor shares. We choose these to match the average factor shares in our data: $s_{l}=0.57$ for labor and (1 $\left.s_{l}\right) s_{e}=0.043$ for energy. The parameters for the energy price, consumer preferences, and the depreciation rate are the same as before.

To solve the model, we follow the solution procedure outlined in Propositions 1-3. In particular, we impose the condition that all types of existing capital are always fully utilized in equilibrium and consider the restricted planning problem. Following Proposition 3, we impose that there is positive investment in at most one type of physical capital in each period. Thus, if we let $x_{t}$ denote the quantity of physical investment and $v_{t}$ denote the type of capital being invested in, constraints (16) and (17) simplify to $z_{t+1}=(1-\delta) z_{t}+x_{t} f\left(v_{t}\right) / v_{t}$ and $m_{t+1}=$ $(1-\delta) m_{t}+x_{t} / v_{t}$. We solve a log-linear approximation to the first-order conditions of this restricted problem around the deterministic steady state with the energy price set to $\bar{p}$ using standard methods.

The final step in our solution procedure is to verify that our assumption that all types of existing capital are always fully utilized is valid for the solution we obtain. In theory, to ensure that this assumption is valid in all states of nature, we must assume that the energy price process has bounded support. In parameterizing the model, we choose a lognormal energy price process which has unbounded support. We choose this price process to make our results more comparable to those in the literature. In practice, when we use this unbounded price process in our simulations, we find that the probability that some type of capital is ever left idle in equilibrium is vanishingly small. In particular, we simulate the model for 10,000 periods and do not find a single period in which this assumption is violated.

This result that all types of capital are fully utilized with probability very close to one can be understood as follows. Let $\bar{v}=\bar{k} / \bar{e}$ be the 
capital-to-energy ratio for existing capital, and let $\bar{v}^{*}$ be the cutoff type of capital for the deterministic steady state of our economy. For our economy, $\bar{v} / \bar{v}^{*}=12.9$ or $\log \bar{v}-\log \bar{v}^{*}=$ 2.6. Log-linearizing the equation $G_{z}(z$, 1) $f\left(v^{*}\right)=p$ that defines the cutoff type of capital $v^{*}$ around the deterministic steady state gives for our parameterization

$$
\begin{aligned}
\log \left(v^{*}\right)-\log \left(\bar{v}^{*}\right) \\
=\frac{s_{l}}{1-s_{e}}(\log z-\log \bar{z}) \\
\quad+\frac{1}{1-s_{e}}(\log p-\log \bar{p})
\end{aligned}
$$

where $z$ is capital services, $s_{e}=0.1$ is the steady-state share of energy in the cost of capital services, and $s_{l}$ is the steady-state share of labor in the cost of output.

In general, this equation is only a first-order approximation to the cutoff rule and thus might be inaccurate far away from the steady state. In our formulation here, however, the production functions $F$ and $G$ are Cobb-Douglas, so this formula is exact. In our simulations, capital services do not move very much. Thus, the energy price must rise so that $\log p-\log \bar{p}=$ 2.3 or $p / \bar{p}=10$ before we must be concerned about leaving the steady-state type of capital idle. The probability that such a movement in energy prices would occur in our model is essentially zero. Indeed, given our price process, an energy price this high would be over seven standard deviations from the mean price, and the probability of such a shock is on the order of $10^{-12}$. The reason for this result is that steadystate energy costs are only $1 / 10$ the costs of capital services; therefore, it takes a huge increase in the price of energy before these costs become larger than the value of the capital services provided by the capital.

To evaluate the ability of this putty-clay model to reproduce our time-series data on the energy price and energy use, we simulate it, feeding in the data on the energy price to obtain predictions for the time paths of energy use, capital, and output. To check our assumption that all capital is fully utilized, we compute the paths for the cutoff type of capital $v_{t}^{*}$ and the type of new capital $v_{t}$ implied by the path of prices realized in the data. Figure 4 shows that for the period 19601994, the cutoffs $v_{t}^{*}$ range from 3.4 to 9.6, while the types $v_{t}$ of new capital range from 51.7 to 92.6 . Clearly, the assumption that all types of capital are fully utilized for the realized path of energy prices is satisfied with a large margin for error.

In Figure 5, we compare the time series for the logarithm of the ratio of energy expenditure to nominal GDP with the ratio of energy use to real GDP in the putty-clay model and the data for the period 1960-1994. Clearly, the model closely tracks the data. In Figure 6, we plot the $\log$ of the capital-to-energy ratio from the puttyclay model and the data for the period 19601994. The responsiveness of the capitalto-energy ratio to changes in the energy price is similar in the model and the data, but this ratio in the model lags that in the data.

Consider now the implications of this model for the cross-section data. Recall that both Griffin and Gregory (1976) and Pindyck (1979) find that the cross-section Allen elasticity of energy use with respect to the energy price is -0.8 , while Pindyck and Rotemberg (1983) find a long-run elasticity of -0.99 . In terms of the cross-section Allen elasticity of capital with respect to the energy price, Griffin and Gregory (1976) find point estimates from 0.08 to 0.17 across countries, while Pindyck's (1979) estimates range from 0.03 to 0.12 . Our model implies a long-run energy elasticity of -0.95 and a long-run capital elasticity of 0.05 , which are in the ranges of the numbers reported above.

We also consider the effect on output of an energy tax that leads to a doubling of energy prices in this putty-clay model. We assume that the revenue collected is spent on public goods that affect neither the steady-state real returns nor the steady-state marginal product of capital. In this model, a doubling of the energy price leads to a 5.5-percent drop in both output and capital stock. The revenue raised from the tax in the long run is 2.4 percent of long-run GDP. The effect of an energy tax on output in this model is an order of magnitude smaller than in the PindyckRotemberg model and comparable to the numbers found in Goulder (1992, 1993, 1995) and Jorgenson and Wilcoxen (1993). 


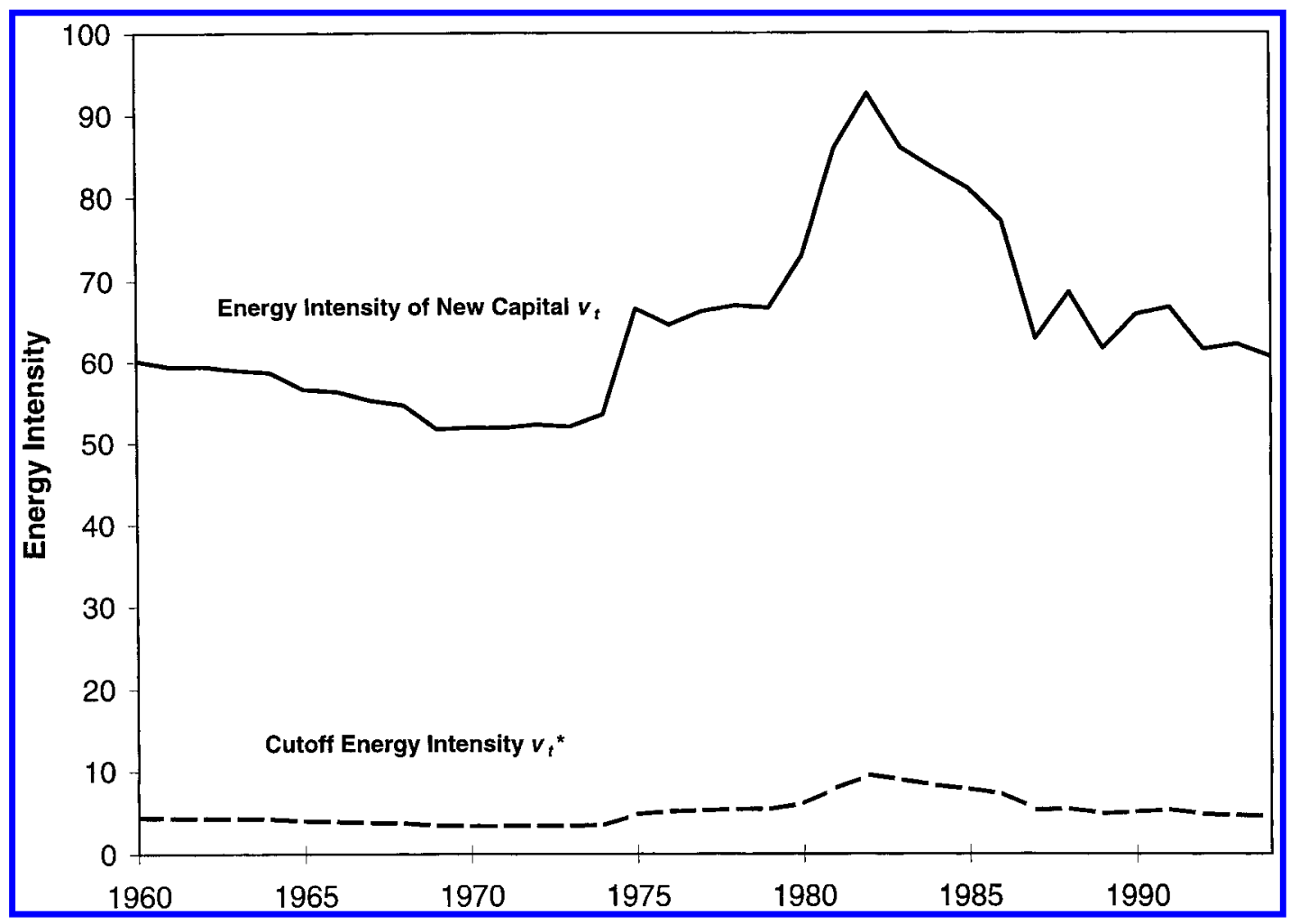

Figure 4. Energy Intensity of New CAPITAL AND the Cutoff Energy InTEnsity 1960-1994

Note: The energy intensity of new capital $v_{t}$ and the cutoff energy intensity $v_{t}^{*}$ for the putty-clay model are determined from equations (19) and (15) in the text given the realized path for the energy price.

\section{Summary and Conclusions}

Energy economists have observed that with respect to the energy price, energy use is inelastic in time-series data and elastic in cross-section data. We have studied two models of energy use that address these observations: a putty-putty model with adjustment costs developed by Pindyck and Rotemberg (1983) and a putty-clay model. Both models can reproduce these differing elasticities; however, they have very different implications for how capital and output respond to permanent differences in energy prices.

In the Pindyck-Rotemberg model, countries with higher energy prices have dramatically lower capital stocks and output. In this respect, the Pindyck-Rotemberg model is not consistent with the cross-section estimates in Griffin and Gregory (1976) and Pindyck (1979) of the responsiveness of capital to the energy price.
Moreover, the effect of an energy tax on output in this model is an order of magnitude larger than numbers found in Goulder (1992, 1993, 1995) and Jorgenson and Wilcoxen (1993).

In the putty-clay model, the response of capital and output to differences in energy prices is similar to that reported in the cross-section studies, and the effect of an energy tax on output is comparable to that found in the tax studies.

\section{APPENDIX}

In this Appendix, we document the construction of the data series we use in the empirical part of the paper. We obtain the raw data from four sources: (1) Survey of Current Business (January 1992), (2) Survey of Current Business (August 1994), (3) Annual Energy Review 1994 (1995), and (4) Citibase (1995). From now on, we refer to these sources as Survey of Current 


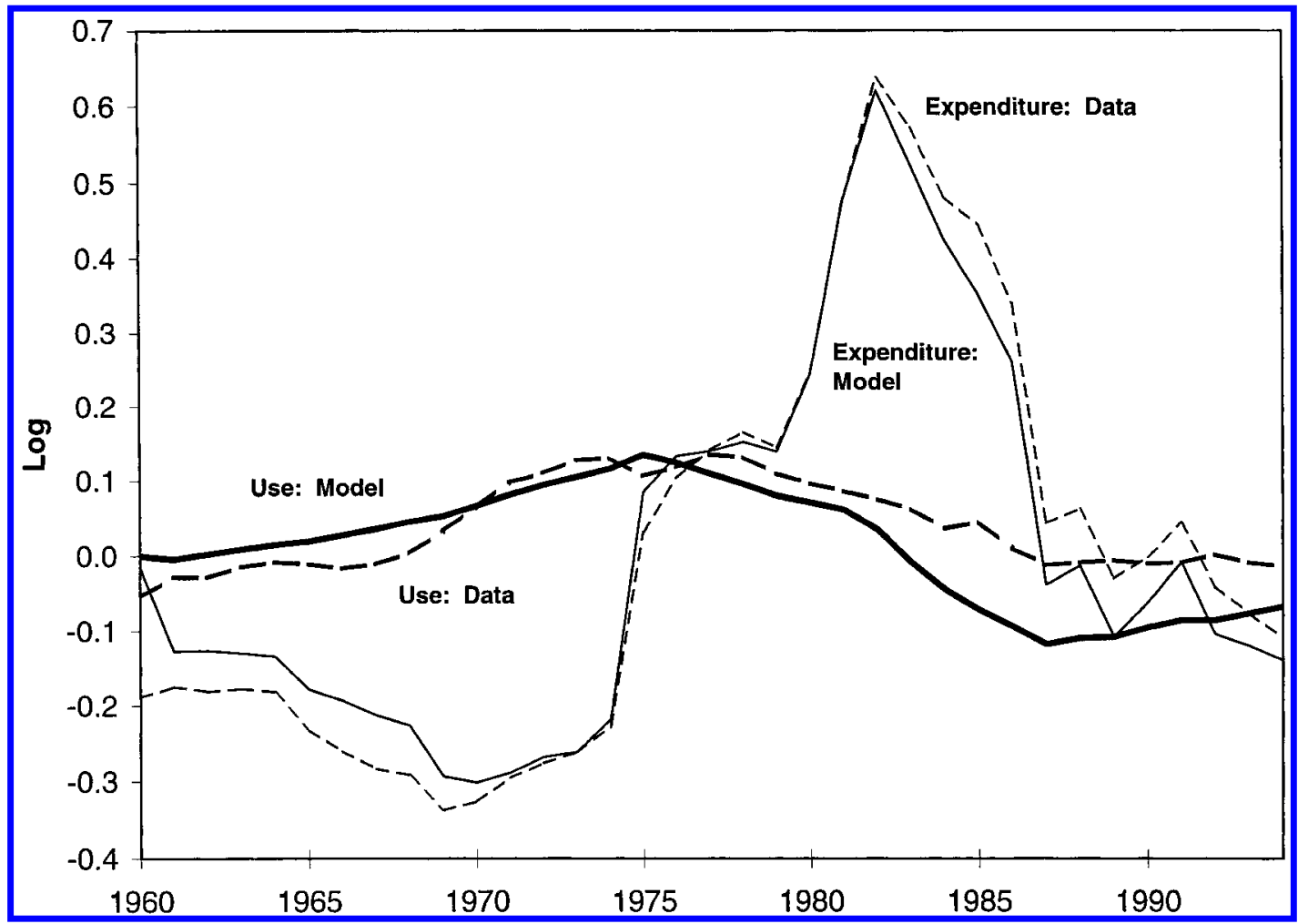

FiguRE 5. ENERGY EXPENDITURE AND USE

Putty-Clay Model versus U.S. Data 1960-1994

Notes: Energy expenditure is the ratio of nominal energy expenditure to nominal GDP; energy use is the ratio of real energy expenditure to real GDP. All series are measured in logarithms and demeaned. See the Appendix for details.

Business 1, Survey of Current Business 2, AER, and Citibase.

\section{Energy Price, Use, and Expenditure Series}

The energy data covers the energy consumption of end users. End users consume energy mainly in four forms: Since our model does not include an energy sector, we subtract the energy use of the energy-producing sectors, namely, the coal, petroleum, natural gas, and electricity sectors. AER (Table 2.1 p. 39) gives data on total energy consumption by end users measured in British thermal units (BTUs) disaggregated into coal, petroleum (and petroleum products), natural gas, and electricity. We denote these data on energy use for each type of energy by $Q_{i t}^{\text {tot }}$, where the index $i=1,2,3,4$ denotes the four forms of energy.
This measure $Q_{i t}^{t o t}$ is already net of energy use of the electricity sector. There are no corresponding data on the energy use by type of the other three energy-producing sectors. There are no data on energy consumption by the natural gas sector. We assume that the energy use of this sector is zero. Data on energy consumption by the coal and petroleum sectors are available from 1974 to 1991 and are not disaggregated into the four forms of energy. We assume that for the years prior to 1974 and following 1991, energy use of these two sectors is equal to the average use in the period 1974-1991. In addition, we assume that the BTUs consumed are divided among the four forms of energy according to the average shares of the industrial sector. These shares are constructed from data on consumption of energy of the industrial sector (AER, Table 2.1 p. 39). Since the absolute value of energy consumption of these 


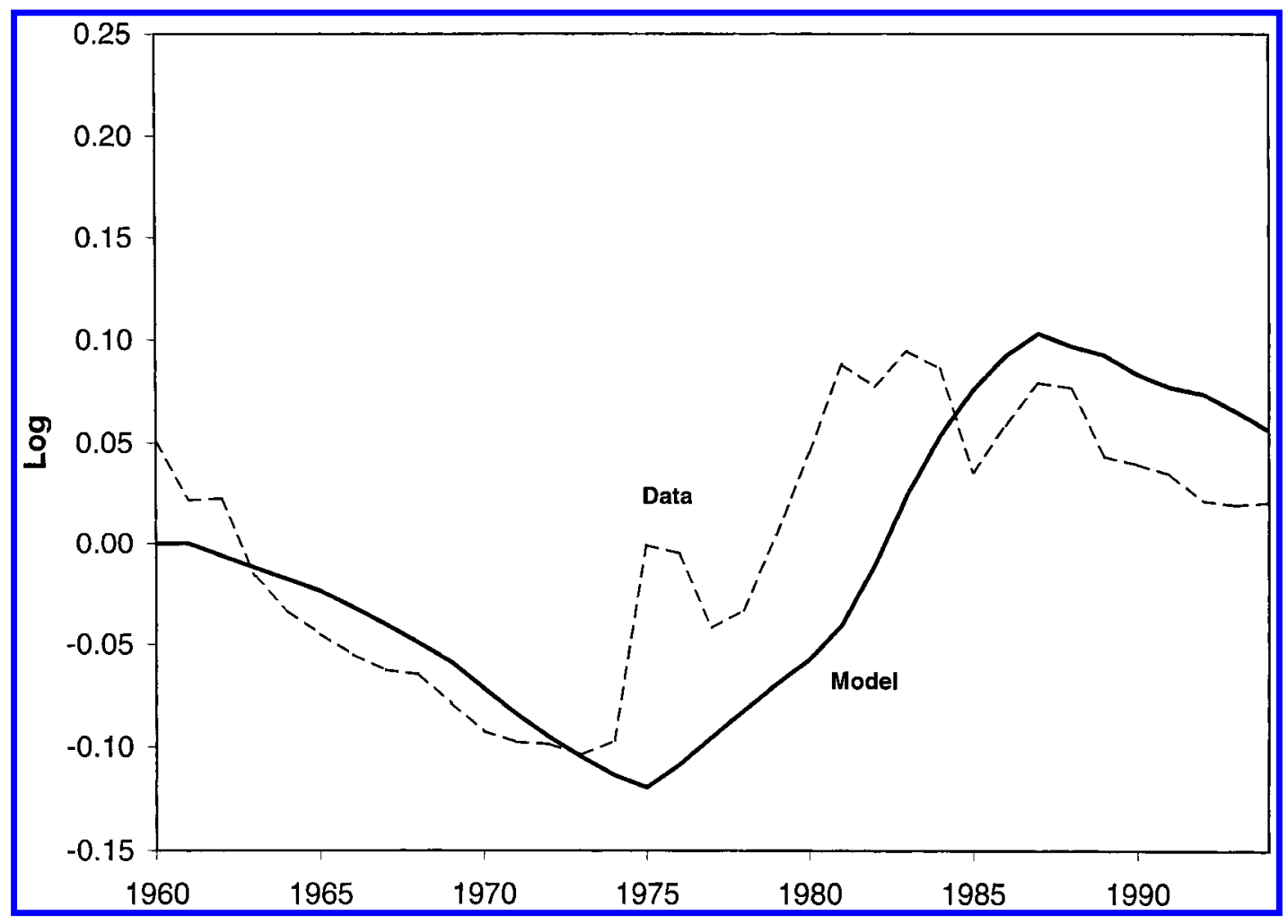

Figure 6. CAPital-Energy Ratio

Putty-Clay Model versus U.S. Data 1960-1994

Notes: Capital-energy ratio is the ratio of the capital stock measured using the perpetual inventory method to real energy expenditure. See the Appendix for details.

two sectors is relatively small, about $1 / 60$ of total energy consumption, the approximations we use should not greatly affect the aggregate series.

We construct a constant-price measure of energy use in the standard fashion. We choose the base year to be 1987 and define energy use to be $e_{t}=\sum_{i} Q_{i t} P_{i 0}$, where $P_{i 0}$ is the price in dollars per BTU of energy of type $i$ in 1987 from AER. For coal, natural gas, and petroleum, we use the production price series (AER, Table 3.1 p. 85). For electricity, we use the retail price of electricity sold by electric utilities. (See AER, Table $8.11 \mathrm{p}$. 249. In Table 8.11, the price for electricity is in cents per kilowatt-hour. We use AER, Table A7 p. 351 to convert the price to cents per BTU.) We construct the energy price deflator as

$$
P_{t}=\frac{\sum_{i} Q_{i t} P_{i t}}{\sum_{i} Q_{i t} P_{i 0}} .
$$

Finally, nominal expenditure is given by $P_{t} e_{t}=$ $\sum_{i} Q_{i t} P_{i t}$.

\section{Output, Consumption, Investment, and the Capital Stock}

We follow the method described by Thomas F. Cooley and Edward C. Prescott (1995 p. 19) to construct broad measures of output, consumption, investment, and the capital stock. For output, investment, and capital, we subtract from each of these series the corresponding series for the energy producing sector. To calculate the output of the energy sector, we sum the value added of the coal, petroleum, electricity, and natural gas sectors. The value added of the coal and petroleum sectors is assumed to be equal to the value of domestic production of the two products. The series of domestic production 
are in the AER (Table 5.1 p. 139 for oil; Table 7.2 p. 211 for coal). The value added of the electricity and the natural gas sectors are reported in Citibase (series GAGUT and GYUT). Real gross output is the sum of value added and the expenditure on energy, namely, $y_{t}+p_{t} e_{t}$. The investment in the energy sectors is defined as the sum of purchases of structures in the electricity, gas, and coal and petroleum mining sectors (series GAPUE, GAPUG, and GANMG in Citibase) plus the purchase of petroleum pipelines (series GAPUO in Citibase). The capital stock of the energy sector $K^{\text {ener }}$ is computed as the capital stock of coal mining, oil and gas extraction, and gas and electricity sectors. The series are found in Survey of Current Business 1 (Table 2 pp. 111-13) for the years 1960-1990 and in Survey of Current Business 2 (Table 2 p. 155) for the years 1991-1993.

\section{REFERENCES}

Annual Energy Review 1994, Energy Information Administration. Washington, DC: U.S. Department of Energy, 1995.

Berndt, Ernst R. and Wood, David O. "Technology, Prices, and the Derived Demand for Energy." Review of Economics and Statistics, August 1975, 57 (3), pp. 259-68.

Cass, David and Stiglitz, Joseph E. "The Implications of Alternative Saving and Expectations Hypotheses for Choices of Technique and Patterns of Growth." Journal of Political Economy, July/August 1969, 77 (4), pp. 586627.

Calvo, Guillermo A. "A Vintage Model of Optimum Economic Growth." Unpublished manuscript, Yale University, 1967. . "Optimal Growth in a Putty-Clay Model." Econometrica, September 1976, 44 (5), pp. 867-78.

Citibase. Macroeconomic database, machinereadable data file. New York: DRI/McGrawHill, 1995.

Cooley, Thomas F. and Prescott, Edward C. "Economic Growth and Business Cycles," in Thomas F. Cooley, ed., Frontiers of business cycle research. Princeton, NJ: Princeton University Press, 1995, pp. 1-38.

Finn, Mary G. "Variance Properties of Solow's Productivity Residual and Their Cyclical Implications." Journal of Economic Dynamics and Control, July-September 1995, 19 (5-7), pp. 1249-81.

Goulder, Lawrence H. "Carbon Tax Design and U.S. Industry Performance," in James M. Poterba, ed., Tax policy and the economy, Vol. 6. Cambridge, MA: MIT Press, 1992, pp. 59-104.

. "Energy Taxes: Traditional Efficiency Effects and Environmental Implications." National Bureau of Economic Research (Cambridge, MA) Working Paper No. 4582, December 1993.

. "Effects of Carbon Taxes in an Economy with Prior Tax Distortions: An Intertemporal General Equilibrium Analysis." Journal of Environmental Economics and Management, November 1995, 29 (3), pp. 271-97.

Griffin, James M. and Gregory, Paul R. "An Intercountry Translog Model of Energy Substitution Responses." American Economic Review, December 1976, 66 (5), pp. 845-57.

Johansen, Leif. "Substitution versus Fixed Production Coefficients in the Theory of Economic Growth: A Synthesis." Econometrica, April 1959, 27 (2), pp. 157-76.

Jorgenson, Dale W. and Wilcoxen, Peter J. "Reducing U.S. Carbon Emissions: An Econometric General Equilibrium Assessment." Resource and Energy Economics, March 1993, 15 (1), pp. 7-25.

-Kim, In Moo and Loungani, Prakash. "The Role of Energy in Real Business Cycle Models." Journal of Monetary Economics, April 1992, 29 (2), pp. 173-89.

Pindyck, Robert S. "Interfuel Substitution and the Industrial Demand for Energy: An International Comparison." Review of Economics and Statistics, May 1979, 61 (2), pp. 169-79.

Pindyck, Robert S. and Rotemberg, Julio J. "Dynamic Factor Demands and the Effects of Energy Price Shocks." American Economic Review, December 1983, 73 (5), pp. 1066-79.

Rotemberg, Julio J. and Woodford, Michael. "Imperfect Competition and the Effects of Energy Price Increases on Economic Activity." Journal of Money, Credit, and Banking, November 1996, 28 (4), pp. 549-77.

Sakellaris, Plutarchos. "Irreversible Capital and the Stock Market Response to Shocks in Profitability." International Economic Review, May 1997, 38 (2), pp. 351-79. 
-Sheshinski, E. "Balanced Growth and Stability in the Johansen Vintage Model." Review of Economic Studies, April 1967, 34 (2), pp. 239-48.

Solow, Robert M. "Substitution and Fixed Proportions in the Theory of Capital." Review of Economic Studies, June 1962, 29 (3), pp. 207-18.
Struckmeyer, Charles S. "The Putty-Clay Perspective on the Capital-Energy Complementarity Debate." Review of Economics and Statistics, May 1987, 69 (2), pp. 320-26.

Survey of Current Business, U.S. Department of Commerce. Washington, DC: Bureau of Economic Analysis, January 1992; August 1994. 


\section{This article has been cited by:}

1. Soma Patra. 2018. ENERGY IN A MODEL OF FIRM ENTRY. Macroeconomic Dynamics 31, 1-24. [Crossref]

2. Renaud Coulomb, Oskar Lecuyer, Adrien Vogt-Schilb. 2018. Optimal Transition from Coal to Gas and Renewable Power Under Capacity Constraints and Adjustment Costs. Environmental and Resource Economics 102. . [Crossref]

3. Yoshio Kajitani, Hirokazu Tatano. 2018. Applicability of a spatial computable general equilibrium model to assess the short-term economic impact of natural disasters. Economic Systems Research 30:3, 289-312. [Crossref]

4. Rob Hart. 2018. Rebound, directed technological change, and aggregate demand for energy. Journal of Environmental Economics and Management 89, 218-234. [Crossref]

5. Samuel Gamtessa, Adugna Berhanu Olani. 2018. Energy price, energy efficiency, and capital productivity: Empirical investigations and policy implications. Energy Economics 72, 650-666. [Crossref]

6. Jianglong Li, Zhi Li. 2018. Understanding the role of economic transition in enlarging energy price elasticity. Economics of Transition 26:2, 253-281. [Crossref]

7. Daniel Aaronson, Eric French, Isaac Sorkin, Ted To. 2018. INDUSTRY DYNAMICS AND THE MINIMUM WAGE: A PUTTY-CLAY APPROACH. International Economic Review 59:1, 51-84. [Crossref]

8. Aktham I. Maghyereh, Basil Awartani, Osama D. Sweidan. 2017. Oil price uncertainty and real output growth: new evidence from selected oil-importing countries in the Middle East. Empirical Economics 64. . [Crossref]

9. César Castro, Rebeca Jiménez-Rodríguez. 2017. Oil price pass-through along the price chain in the euro area. Energy Economics 64, 24-30. [Crossref]

10. Samuel Faye Gamtessa. 2017. The effects of energy price on energy intensity: evidence from Canadian manufacturing sector. Energy Efficiency 10:1, 183-197. [Crossref]

11. Dirk Jan van de Ven, Roger Fouquet. 2017. Historical energy price shocks and their changing effects on the economy. Energy Economics 62, 204-216. [Crossref]

12. Gábor Uliha. 2016. Az olajár gyengülő makrogazdasági hatásai. Két versengő elmélet szintézise. Közgazdasági Szemle 63:7-8, 787-818. [Crossref]

13. Jianglong Li, Boqiang Lin. 2016. Inter-factor/inter-fuel substitution, carbon intensity, and energyrelated CO 2 reduction: Empirical evidence from China. Energy Economics 56, 483-494. [Crossref]

14. Pu-yan Nie, Yong-cong Yang. 2016. Effects of energy price fluctuations on industries with energy inputs: An application to China. Applied Energy 165, 329-334. [Crossref]

15. Hirokazu Ishise. 2016. Capital heterogeneity as a source of comparative advantage: Putty-clay technology in a ricardian model. Journal of International Economics 99, 223-236. [Crossref]

16. Hanna Hottenrott, Sascha Rexhäuser, Reinhilde Veugelers. 2016. Organisational change and the productivity effects of green technology adoption. Resource and Energy Economics 43, 172-194. [Crossref]

17. Arturo Macías, Mariano Matilla-García. 2015. Net energy analysis in a Ramsey-Hotelling growth model. Energy Policy 86, 562-573. [Crossref]

18. Boqiang Lin, Jianglong Li. 2015. The Determinants of Endogenous Oil Price: Considering the Influence from China. Emerging Markets Finance and Trade 51:5, 1034-1050. [Crossref] 
19. Saeed Moshiri. 2015. Asymmetric effects of oil price shocks in oil-exporting countries: the role of institutions. OPEC Energy Review 39:2, 222-246. [Crossref]

20. Peter Egger, Sergey Nigai. 2015. Energy Demand and Trade in General Equilibrium. Environmental and Resource Economics 60:2, 191-213. [Crossref]

21. Ana María Herrera, Latika Gupta Lagalo, Tatsuma Wada. 2015. Asymmetries in the response of economic activity to oil price increases and decreases?. Journal of International Money and Finance 50, 108-133. [Crossref]

22. Antonio García-Olivares, Joaquim Ballabrera-Poy. 2015. Energy and mineral peaks, and a future steady state economy. Technological Forecasting and Social Change 90, 587-598. [Crossref]

23. Jaromir Benes, Marcelle Chauvet, Ondra Kamenik, Michael Kumhof, Douglas Laxton, Susanna Mursula, Jack Selody. 2015. The future of oil: Geology versus technology. International Journal of Forecasting 31:1, 207-221. [Crossref]

24. Lutz Kilian. 2014. Oil Price Shocks: Causes and Consequences. Annual Review of Resource Economics 6:1, 133-154. [Crossref]

25. Jevgenijs Steinbuks, Karsten Neuhoff. 2014. Assessing energy price induced improvements in efficiency of capital in OECD manufacturing industries. Journal of Environmental Economics and Management 68:2, 340-356. [Crossref]

26. Panagiotis Rafailidis, Constantinos Katrakilidis. 2014. The relationship between oil prices and stock prices: a nonlinear asymmetric cointegration approach. Applied Financial Economics 24:12, 793-800. [Crossref]

27. Isaac Sorkin. 2014. Are there long-run effects of the minimum wage?. Review of Economic Dynamics . [Crossref]

28. Ruben Bibas, Aurélie Méjean. 2014. Potential and limitations of bioenergy for low carbon transitions. Climatic Change 123:3-4, 731-761. [Crossref]

29. Stefan F. Schubert. 2014. DYNAMIC EFFECTS OF OIL PRICE SHOCKS AND THEIR IMPACT ON THE CURRENT ACCOUNT. Macroeconomic Dynamics 18:02, 316-337. [Crossref]

30. 2013. Book Reviews. Journal of Economic Literature 51:4, 1183-1208. [Citation] [View PDF article] [PDF with links]

31. Albert G. Hu. 2013. Economic Systems: Private Rights and Public Problems: The Global Economics of Intellectual Property in the 21st Century. Journal of Economic Literature 51:4, 1206-1208. [Abstract] [View PDF article] [PDF with links]

32. Jesse Perla. 2013. Economic Development, Technological Change, and Growth: The Growth Spiral: Money, Energy, and Imagination in the Dynamics of the Market Process. Journal of Economic Literature 51:4, 1205-1206. [Abstract] [View PDF article] [PDF with links]

33. Claudia Ghisetti, Francesco Quatraro. 2013. Beyond inducement in climate change: Does environmental performance spur environmental technologies? A regional analysis of cross-sectoral differences. Ecological Economics 96, 99-113. [Crossref]

34. Henri Waisman, Julie Rozenberg, Jean Charles Hourcade. 2013. Monetary compensations in climate policy through the lens of a general equilibrium assessment: The case of oil-exporting countries. Energy Policy 63, 951-961. [Crossref]

35. Zeynel Abidin Ozdemir, Korhan Gokmenoglu, Cagdas Ekinci. 2013. Persistence in crude oil spot and futures prices. Energy 59, 29-37. [Crossref]

36. Libo Wu, Jing Li, ZhongXiang Zhang. 2013. Inflationary effect of oil-price shocks in an imperfect market: A partial transmission input-output analysis. Journal of Policy Modeling 35:2, 354-369. [Crossref] 
37. Thomas A. Knetsch, Alexander Molzahn. 2012. Supply-side effects of strong energy price hikes in German industry and transportation. Empirical Economics 43:3, 1215-1238. [Crossref]

38. Alessandro Maravalle. 2012. The role of the trade channel in the propagation of oil supply shocks. Energy Economics 34:6, 2135-2147. [Crossref]

39. Henri Waisman, Julie Rozenberg, Olivier Sassi, Jean-Charles Hourcade. 2012. Peak Oil profiles through the lens of a general equilibrium assessment. Energy Policy 48, 744-753. [Crossref]

40. Natali Hritonenko, Yuri Yatsenko. 2012. Energy substitutability and modernization of energyconsuming technologies. Energy Economics 34:5, 1548-1556. [Crossref]

41. NICOLAE GÂRLEANU, STAVROS PANAGEAS, JIANFENG YU. 2012. Technological Growth and Asset Pricing. The Journal of Finance 67:4, 1265-1292. [Crossref]

42. Ricardo Guerrero-Lemus, Gustavo A. Marrero, Luis A. Puch. 2012. Costs for conventional and renewable fuels and electricity in the worldwide transport sector: A mean-variance portfolio approach. Energy 44:1, 178-188. [Crossref]

43. Johannes Truby, Moritz Paulus. 2012. Market Structure Scenarios in International Steam Coal Trade. The Energy Journal 33:3. . [Crossref]

44. JEAN-MARC NATAL. 2012. Monetary Policy Response to Oil Price Shocks. Journal of Money, Credit and Banking 44:1, 53-101. [Crossref]

45. James D. Hamilton. 2011. NONLINEARITIES AND THE MACROECONOMIC EFFECTS OF OIL PRICES. Macroeconomic Dynamics 1-15. [Crossref]

46. Beatriz Gaitan, Terry L. Roe. 2011. International trade, exhaustible-resource abundance and economic growth. Review of Economic Dynamics . [Crossref]

47. Javier Ordonez, Hector Sala, Jose' Silva. 2011. Oil Price Shocks and Labor Market Fluctuations. The Energy Journal 32:3. . [Crossref]

48. François Gourio. 2011. Putty-clay technology and stock market volatility. Journal of Monetary Economics 58:2, 117-131. [Crossref]

49. Martin Bodenstein, Christopher J. Erceg, Luca Guerrieri. 2011. Oil shocks and external adjustment. Journal of International Economics 83:2, 168-184. [Crossref]

50. David I. Stern. 2011. The role of energy in economic growth. Annals of the New York Academy of Sciences 1219:1, 26-51. [Crossref]

51. Stefan F. Schubert, Stephen J. Turnovsky. 2011. The impact of oil prices on an oil-importing developing economy. Journal of Development Economics 94:1, 18-29. [Crossref]

52. Valerie A. Ramey, Daniel J. Vine. 2011. Oil, Automobiles, and the U.S. Economy: How Much Have Things Really Changed?. NBER Macroeconomics Annual 25:1, 333-368. [Crossref]

53. Yu Hong, Hong-wei Su. Can energy price shocks drive long-run technological progress and growth? \&\#8212;Empirical evidence from Korea 656-660. [Crossref]

54. Théo Naccache. 2010. Slow oil shocks and the "weakening of the oil price-macroeconomy relationship”. Energy Policy 38:5, 2340-2345. [Crossref]

55. Fabio Milani. 2009. Expectations, learning, and the changing relationship between oil prices and the macroeconomy\#. Energy Economics 31:6, 827-837. [Crossref]

56. JOSHUA LINN. 2009. WHY DO ENERGY PRICES MATTER? THE ROLE OF INTERINDUSTRY LINKAGES IN U.S. MANUFACTURING. Economic Inquiry 47:3, 549-567. [Crossref]

57. Pascal Jacquinot, Mika Kuismanen, Ricardo Mestre, Martin Spitzer. 2009. An Assessment of the Inflationary Impact of Oil Shocks in the Euro Area. The Energy Journal 30:1. . [Crossref] 
58. François Lescaroux, Valérie Mignon. 2008. On the influence of oil prices on economic activity and other macroeconomic and financial variables. OPEC Energy Review 32:4, 343-380. [Crossref]

59. Lutz Kilian. 2008. The Economic Effects of Energy Price Shocks. Journal of Economic Literature 46:4, 871-909. [Abstract] [View PDF article] [PDF with links]

60. Joshua Linn. 2008. Energy Prices and the Adoption of Energy-Saving Technology*. The Economic Journal 118:533, 1986-2012. [Crossref]

61. RAJEEV DHAWAN, KARSTEN JESKE. 2008. Energy Price Shocks and the Macroeconomy: The Role of Consumer Durables. Journal of Money, Credit and Banking 40:7, 1357-1377. [Crossref]

62. D ZHANG. 2008. Oil shock and economic growth in Japan: A nonlinear approach. Energy Economics 30:5, 2374-2390. [Crossref]

63. Paresh Kumar Narayan, Seema Narayan, Russell Smyth. 2008. Are oil shocks permanent or temporary? Panel data evidence from crude oil and NGL production in 60 countries. Energy Economics 30:3, 919-936. [Crossref]

64. Sandrine Lardic, Valérie Mignon. 2008. Oil prices and economic activity: An asymmetric cointegration approach. Energy Economics 30:3, 847-855. [Crossref]

65. James D. Hamilton. Oil and the Macroeconomy 1-7. [Crossref]

66. Chun-Yu Ho, Kam Wing Siu. 2007. A dynamic equilibrium of electricity consumption and GDP in Hong Kong: An empirical investigation. Energy Policy 35:4, 2507-2513. [Crossref]

67. Sandrine Lardic, Valérie Mignon. 2006. The impact of oil prices on GDP in European countries: An empirical investigation based on asymmetric cointegration. Energy Policy 34:18, 3910-3915. [Crossref]

68. William A. Pizer, Raymond Kopp. Chapter 25 Calculating the Costs of Environmental Regulation 1307-1351. [Crossref]

69. Simon Gilchrist, John C. Williams. 2005. Investment, capacity, and uncertainty: a putty-clay approach. Review of Economic Dynamics 8:1,1-27. [Crossref]

70. Thomas F. Cooley, Vincenzo Quadrini. 2003. Common Currencies vs. Monetary Independence. Review of Economic Studies 70:4, 785-806. [Crossref]

71. J Hamilton. 2003. What is an oil shock?. Journal of Econometrics 113:2, 363-398. [Crossref]

72. Chao Wei. 2003. Energy, the Stock Market, and the Putty-Clay Investment Model. American Economic Review 93:1, 311-323. [Citation] [View PDF article] [PDF with links]

73. Nathan S. Balke, Stephen P.A. Brown, Mine K. Yucel. 2002. Oil Price Shocks and the U.S. Economy: Where Does the Asymmetry Originate?. The Energy Journal 23:3. . [Crossref]

74. K Lee. 2002. On the dynamic effects of oil price shocks: a study using industry level data. Journal of Monetary Economics 49:4, 823-852. [Crossref]

75. Jesper Jensen, Tobias N. Rasmussen. 2000. Allocation of CO2 Emissions Permits: A General Equilibrium Analysis of Policy Instruments. Journal of Environmental Economics and Management 40:2, 111-136. [Crossref] 